Published by the University of KwaZulu-Natal https://journals.ukzn.ac.za/index.php/JICBE

(C) Creative Commons With Attribution (CC-BY)

Journal of Inclusive cities and Built environment. Vol. 1 Issue 2

How to cite: Nzimande-Mbele N. et. al. 2021. Integration of the demographic dividend into government plans: A case of the KwaZulu-Natal Province of South Africa. Journal of Inclusive cities and Built environment. Vol. 1 Issue 2, Pg 89-102.

\title{
INTEGRATION OF THE DEMOGRAPHIC DIVIDEND INTO GOVERNMENT PLANS: A CASE OF THE KWAZULU-NATAL PROVINCE OF SOUTH AFRICA
}

\author{
By Nzimande-Mbele N., Magidimisha-chipungu H., Naidoo L., Mbalo M., Dlamini N., Bhengu S., \\ Gelebe V., North H. and Creighton A.
}

Published 25th October 2021

\begin{abstract}
The Population reference Bureau policy brief, (Gribble and Bremmer, 2012):1) described the demographic dividend as "...the accelerated economic growth that may result from a decline in a country's mortality and fertility and the subsequent change in the age structure of the population. With fewer births each year, a country's young dependent population grows smaller in relation to the working-age population. With fewer people to support, a country has a window of opportunity for rapid economic growth if the right social and economic policies developed and investments made". Several South Africa based studies have explored age structure and the prospects of a demographic dividend. These studies range from those that explore timing of the dividend to those that investigate readiness to harness the dividend. Three aspects of the demographic dividend are investigated by this research. Firstly, the paper will explore the age structure of KwaZulu-Natal population to ascertain the timing of the age-structure (youth bulge) that is a pre-requisite for the dividend. Secondly, demographic, health and education characteristics that are knows to affect the achievement of the dividend will be examined. Lastly, the extent of integration of the demographic dividend into Integrated Development Plans (IDPs) in the province will be explored.
\end{abstract}

KEY WORDS Integrated Development Plan, Demographic Divided, Kwazulu-Natal

Mbele N. and Magidimisha-chipungu H. - University of KwaZulu-Natal

Naidoo L. - UNFP

Mbalo M. and Bhengu S.- KZN Population Unit

Gelebe V. - KZN COGTA

North H. and Creighton A.- KZN Statistics South Africa 


\section{BACKGROUND AND INTRODUCTION}

The Population reference Bureau policy brief, ((Gribble and Bremmer, 2012):1) described the demographic dividend as "...the accelerated economic growth that may result from a decline in a country's mortality and fertility and the subsequent change in the age structure of the population. With fewer births each year, a country's young dependent population grows smaller in relation to the workingage population. With fewer people to support, a country has a window of opportunity for rapid economic growth if the right social and economic policies developed and investments made". Two aspects of this explanation will be investigated by this research. Firstly, the paper will explore the age structure of KwaZulu-Natal population to ascertain the timing of the age-structure (youth bulge) that is a pre-requisite for the dividend. Secondly, demographic, health and education characteristics that are knows to affect the achievement of the dividend will be examined, lastly the extent of integration of the demographic dividend into Integrated Development Plans (IDPs) in the province will be explored.

Several studies have explored the benefits of the demographic dividend in various parts of the world. The United Nations (UN) expert group on social and economic implications of changing population age structure, published proceedings from a meeting in Mexico City in 2005. In the report were several studies that outlined age structures of various developing countries and the stages of success in harnessing the demographic dividend (United-Nations, 2007). Furthermore, a comprehensive study that explored age structures of UN world regions concluded that the first dividend is at its initial stages in sub/-Saharan Africa, although individual countries are at different levels (Mason, 2007). A study in Mexico also presented in this report, discusses strategies and programmes that were designed in Mexico to promote human capital given prevailing age-structure, whose effectiveness is yet to be assessed given that the period of a youth bulge is still underway (Virgilio, 2007).

Several South Africa based studies have explored age structure and the prospects of a demographic dividend. These studies range from those that explore timing of the dividend to those that investigate readiness to harness the dividend (Kaufman, 1998). (Oosthuizen, 2015) explored South Africa's agestructure and assessed the effect of fertility, labour income and consumption on prospects of the dividend in the country. He concluded that "the evidence suggests that the country has already passed through a significant proportion of its first demographic dividend" ((Oosthuizen, 2015):20). Among components of demographic change, the paper emphasized the important role played by fertility in determining the amount of gain that will be accrued from the dividend. On this aspect, Oosthuizen (2015:21) suggests that "lowered fertility is expected to boost the magnitude of the dividend, but will also slightly compress the remaining period of positive dividend". The paper made this conclusion by simulating outcomes of several fertility scenarios. Our research will add value by observing levels of fertility in the province with the third highest level of fertility and draw conclusion on the burden of fertility on harnessing the demographic dividend.

\section{THE DEMOGRAPHIC DIVIDEND (DD) AND INTEGRATION DEVELOPMENT PLANS (IDPS)}

Integrated Development Plan (IDP) documents for district municipalities in KwaZulu-Natal (KZN) have been a staple in development planning in the last decade. In recent years, there has been increasing criticism of IDP reports on the basis that they appear to have a misalignment of the various stages of the IDP process. For instance, the situation analysis and identified projects funded in the municipal budget through the IDP appear to be less informed by local demographic data. What has been rather glaring is the absence of sufficient demographic detail informing the strategies and projects adopted in most 2019/20 IDP reports for $\mathrm{KZN}$ district municipalities that were reviewed. Moreover, there is some indication that demographic data has not always been used effectively in the IDP process, even by experienced planners. This paper therefore aim to increase knowledge and understanding of the importance of demographic data with a view to promoting its effective use. The methodology used in this review is based on document/content analysis, which is a systematic procedure for reviewing or evaluating printed and electronic documents. We selected this method for its capability to allow for IDPs to be examined and interpreted in order to elicit meaning, gain understanding and draw conclusions (Bowen, 2009; Corbin \& Strauss, 2008).

Exploring the IDPs for mainstreaming the demographic dividend involve various steps. The schematic presentation of the three phases of programming the DD with its associated nine steps is shown in Figure 1. The three phases are recommended by the UNFPA as preparation, planning and implementation (United-NationsPopulation-Fund, 2018). We will utilize these programming steps to assess the DD at a district level.

Although age-structure is a prerequisite, it is not the exhaustive requirement for countries to reap the demographic dividend. The dividend is delivered through labour supply, savings and human capital (Bloom et al., 2002). Therefore, each aspect has to be explored. Investments in youth is therefore located at the center of the planning strategies, towards ensuring that this population group can contribute to towards sustainable development. Pillars that have been identified as crucial to achieve this in $K Z N$ include but not limited to - employment and entrepreneurship, education and skills development, health and wellbeing, and lastly, rights and youth empowerment. 
Harnessing the demographic dividend requires key actions from all aspects of development planning and nation-building. Local government therefore should (1) understand the demographic composition and its prospects, (2) incorporate this into all spheres of planning, and (2) develop programs that will realize the full potential of its population. Guiding principles designed to develop an enabling environment for reaping he dividend have been proffered. These emphasize the need to be guided by the core principles of Agenda 2063 and the 2030 Agenda for Sustainable Development especially as relates to a people-centred approach to development and a commitment to leave no one behind (African-Union, 2017).

Figure 1: Programming steps for achieving the DD

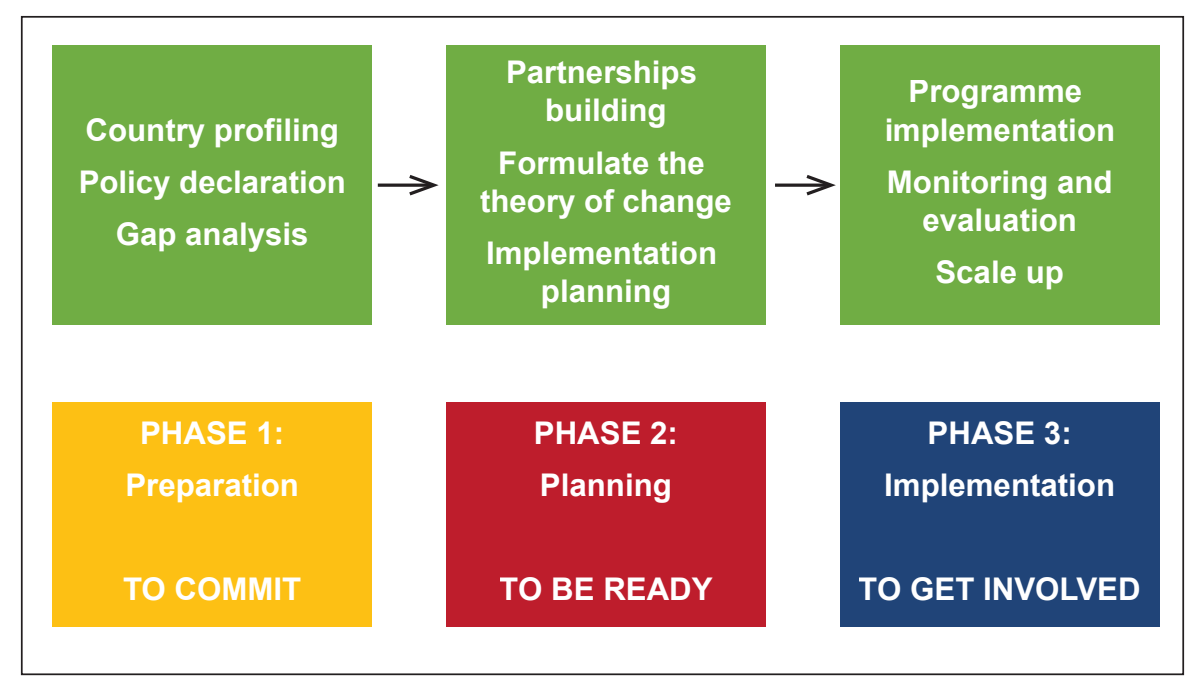

Source: (United-Nations-Population-Fund, 2018)

\section{KWAZULU-NATAL DEMOGRAPHIC PROSPECTS}

Figure 2 presents the age structure of KwaZulu-Natal from population censuses and the 2019 mid-year estimates (Statistics South Africa, 2019). The main observation from the population pyramids is the emergence of a youth bulge, which commenced in 2001 from a cohort of 0-14 in 1996. The percentage of the youth population (15-15 years old) as a component of the total KwaZuluNatal population grew from to $29.5 \%$ in 1996; 36.7 in 2001; 38.3 in 2011 and then declined to $36.8 \%$ in 2019. The total population of the province grew from $8,298,509$ in $2019,9,426,018$ in $2001,10,267,301$ to $11,503,917$ in 2019 . The population grew by one per cent between 2001 and 2011 as opposed to a two per cent growth between 1996 and 2001. This is mostly attributable to a continuous fertility decline in South Africa since the 1960s. It is impossible to rule out the impact of HIV and AIDS in the reduction of the growth rate of the population of KwaZulu-Natal given the HIV related mortality in the province. As such, it remains unclear whether the switch in the provincial population size observed between 2001 and 2011 - where KwaZulu-Natal lost its rank as the most populous province in South Africa to Gauteng - is a result of high HIV-mortality during this period, increased migration out of the province, or high migration into Gauteng.

The rate of growth is also increasing to the average of $2 \%$ between 2011 and 2019 as shown in Figure 3. Also noticeable is the population younger than 10 years of age. This population is large in 2011 and larger in 2019. Although this is not a due to fertility, but a larger youthful population - the emergence of a large child population require special attention during planning. 
Figure 2: Age-sex structure of KwaZulu-Natal population
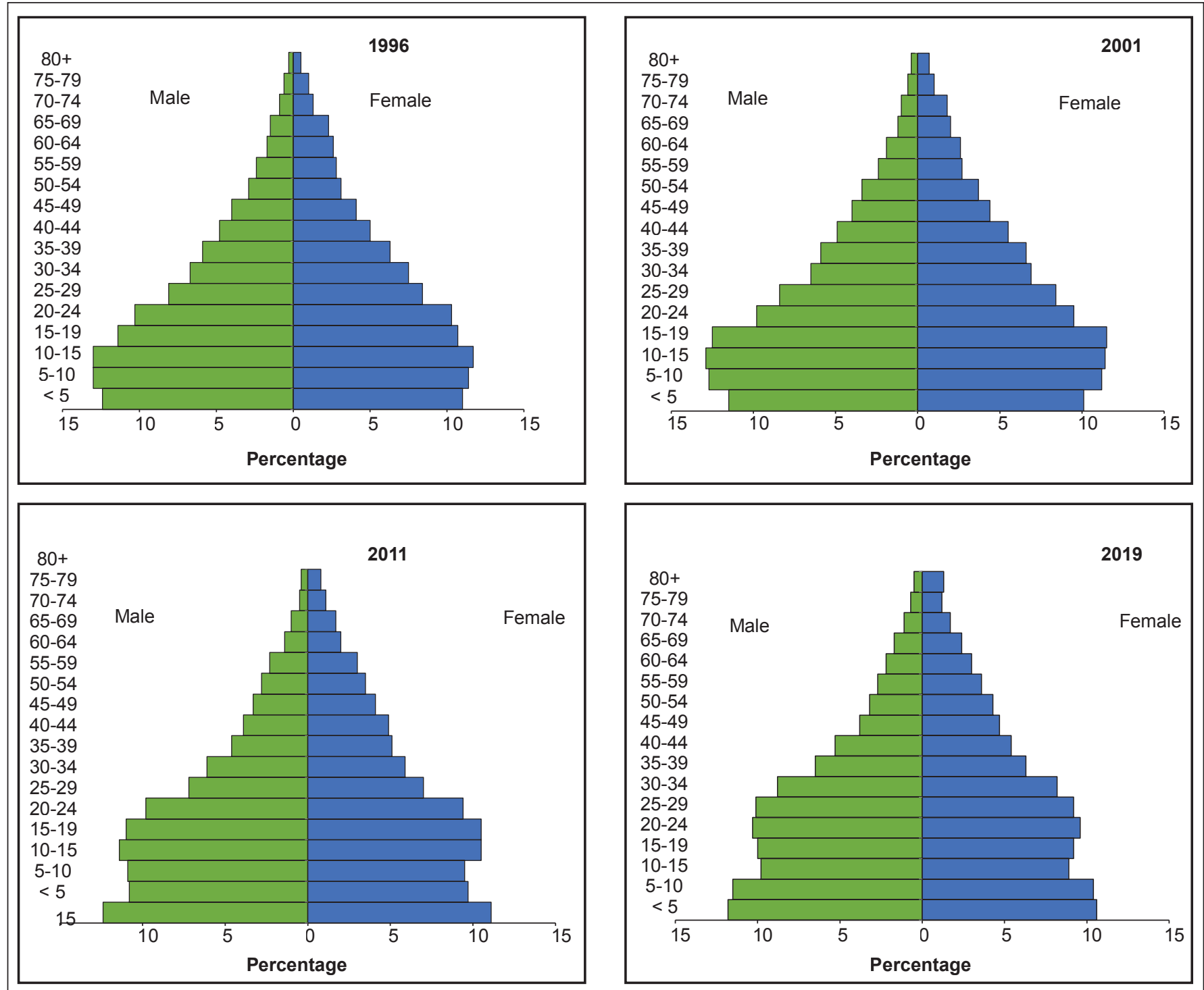

Figure 3: KwaZulu-Natal population growth

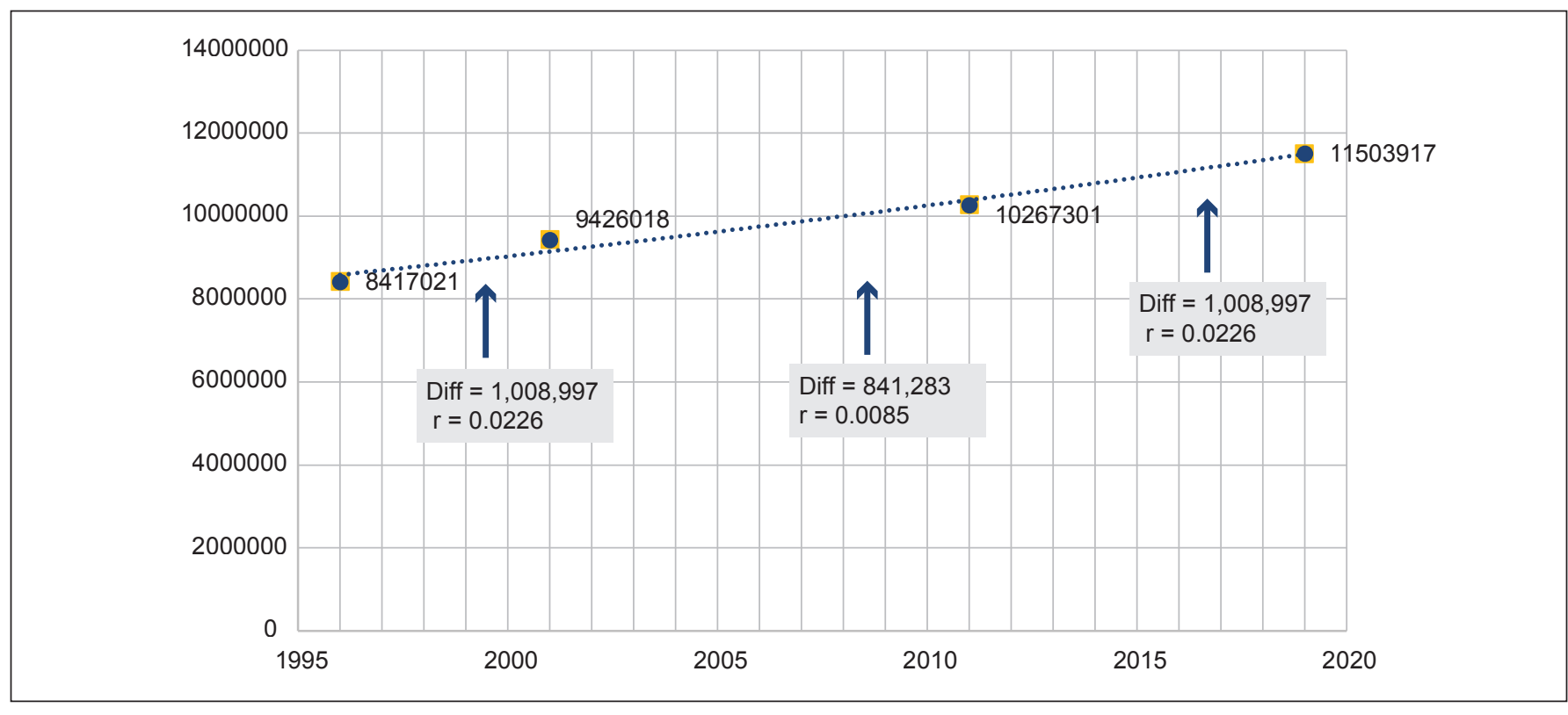


The age-structure of 2019 show a $4 \%$ reversal of the increase in the size of the youth population in 2016. The main outcome of demographic transition that result to the demographic dividend is that "larger share of the population becomes concentrated in the highly productive working ages" (United Nations Population Fund, 2002: 40). The KwaZulu-Natal age structure from the three population censuses and 2019 midyear estimates (shown in Figure 2) suggests that the window of youth bulge, which is a pre-condition for a dividend, commenced in 2001; reached its peak between 2011 and 2019. The decline in the percentage of youth population as a component of the total KwaZulu-Natal population does not mark the end of a dividend period. In fact, the emergence of a larger population below the ages of 10 suggests that the province will have another youth bulge in 10 to 20 years time. This however will be accompanied with a large population in late adulthood $(45+)$ from the current youth bulge. The contribution of functional ages (shown in Figure 4) is one of critical indicators for planning. Unlike typical developing country profiles (with large population under the age of 15), the provincial share suggest a large economic age group (15-64 years) that has been consistent over-time.

Figure 4: Percentage contribution of functional ages to total population

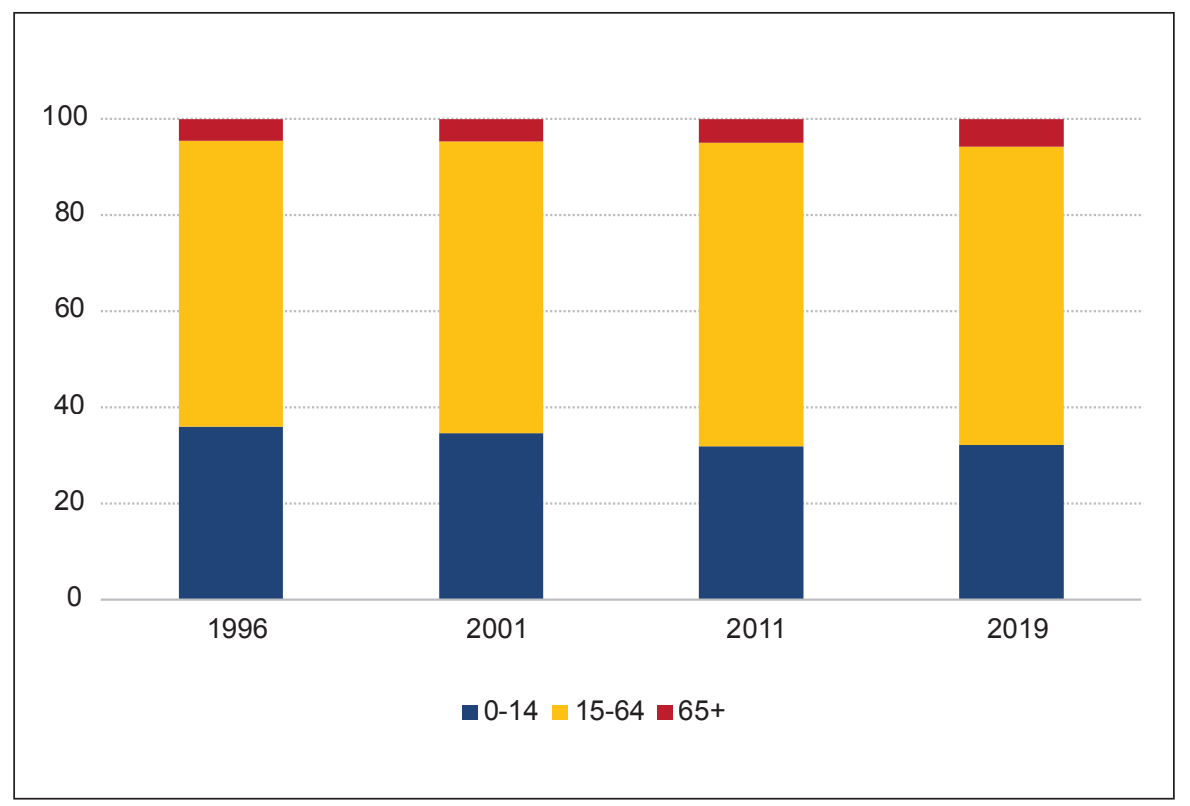

Figure 5: Intercensal growth rates

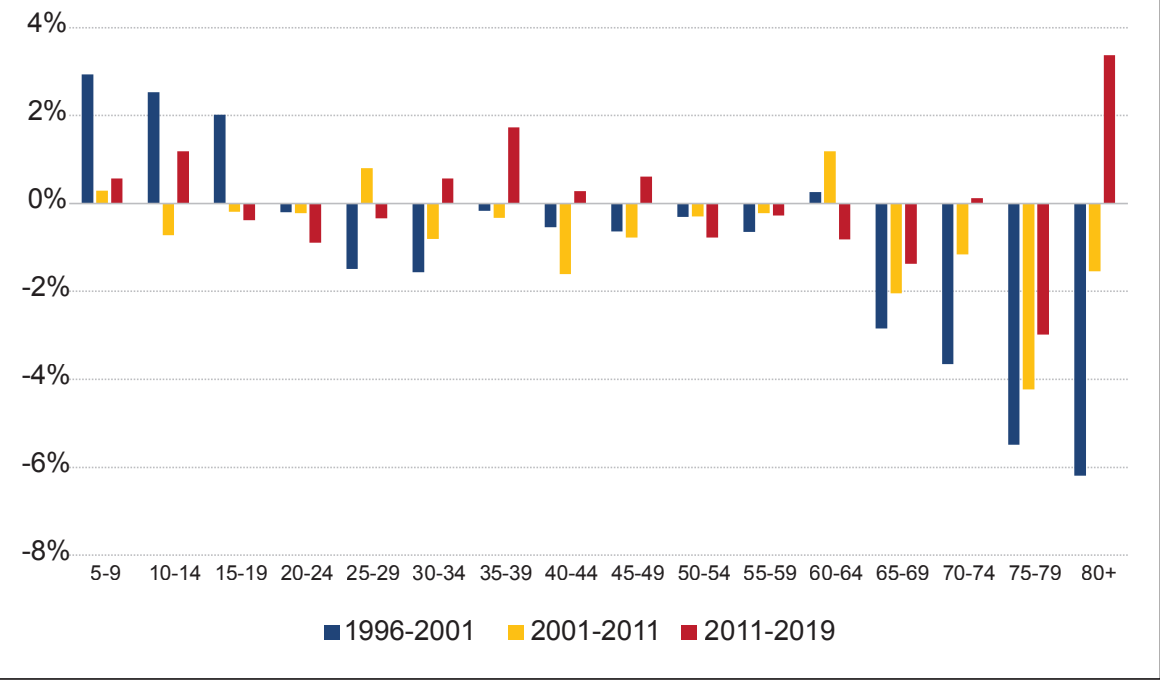

The actual age-specific intercensal rate of growth is further explored in Figure 5. The intercensal growth rate was estimated to assess cohort growth in population between census years. Generally, except in cases of high migration, this growth is less likely to be above $3.5 \%$. The cohort growth rate is estimated as

$$
r=\frac{\ln \left(\frac{N\left(t_{2}\right)}{N\left(t_{1}\right)}\right)}{\left(t_{2}-t_{1}\right)}
$$

Where $N(t 1)$ is the population at time $1(\mathrm{t} 1)$, and $\mathrm{N}(\mathrm{t} 2)$ is the population at time 2 (Moultrie, 2013). The growth rates are highest in younger ages between the 1996 and 2001, when fertility was higher. All other age-groups show very little growth, suggesting stability in population change - and mostly suggest that the provincial population is growing through natural increase. A decline in cohorts after the age of 65 , which is attributable to mortality.

\subsection{Fertility}

Results from the latest South Africa Demographic and Health Survey (SADHS) conducted in 2016 show that the average number of children born by women in reproductive ages was 2.6 for South Africa and 2.5 for KwaZulu-Natal. The average number of wanted children by women in the province was 1.8 , suggesting a difference of 0.7 .

Sexual and reproductive health and rights (SRHR) is critical in securing the human development potential, especially for women. In a high fertility province such as $K Z N$, understanding the nature of SRHR is paramount. $20.7 \%$ of $\mathrm{KZN}$ women in reproductive ages had unmet needs for family planning. This was the third highest after Limpopo (24.7\%) and Eastern Cape (20.8\%). Surprisingly the province had the higher prevalence of contraceptive use in the country based on the survey at $65 \%$. 


\subsection{District age-sex structures}

KwaZulu-Natal Districts are not homogenous. The aggregate age-sex structure masks District level variation as it is skewed more towards Districts that have the largest population size, i.e. the Metro and the Capital City. Figure 6 show the age-structure of EThekwini District Municipality, which has the largest population size in the population. EThekwini Municipality had a population of $4,134,487$ in 2019 , which is expected to grow to $4,444,516$ by 2023 . The age-structure suggests that the Metro is experiencing a youth bulge, also shown in the dependency ratio of 43.5 in 2019 . The population between the ages of 25 to 39 is the largest share of the total population. There is also a larger number of children between the ages of 0 to 9 , which suggests that another youth bulge can be expected in 10 to 15 years. Figure 7 show the age-structure of remaining 10 KZN Districts. The Districts were further classified it terms of their position in the demographic transition. As such, they were classified as pre-transition (Harry Gwala DM, UMkhanyakude DM, and Zululand DM), early transition (Amajuba DM, King Cetshwayo DM, ILembe DM, Ugu DM, UMzinyathi DM, and UThukela DM), mid-transition, and late-transition (EThekwini DM and UMgungundlovu DM). Furthermore, DMs were classified as pre-dividend if their age structure does not show a youth bulge and mid-dividend for those with a large youth population. These classifications are shown in Table 2.

Figure 6: (a) Age-specific fertility rates (b) EThekwini
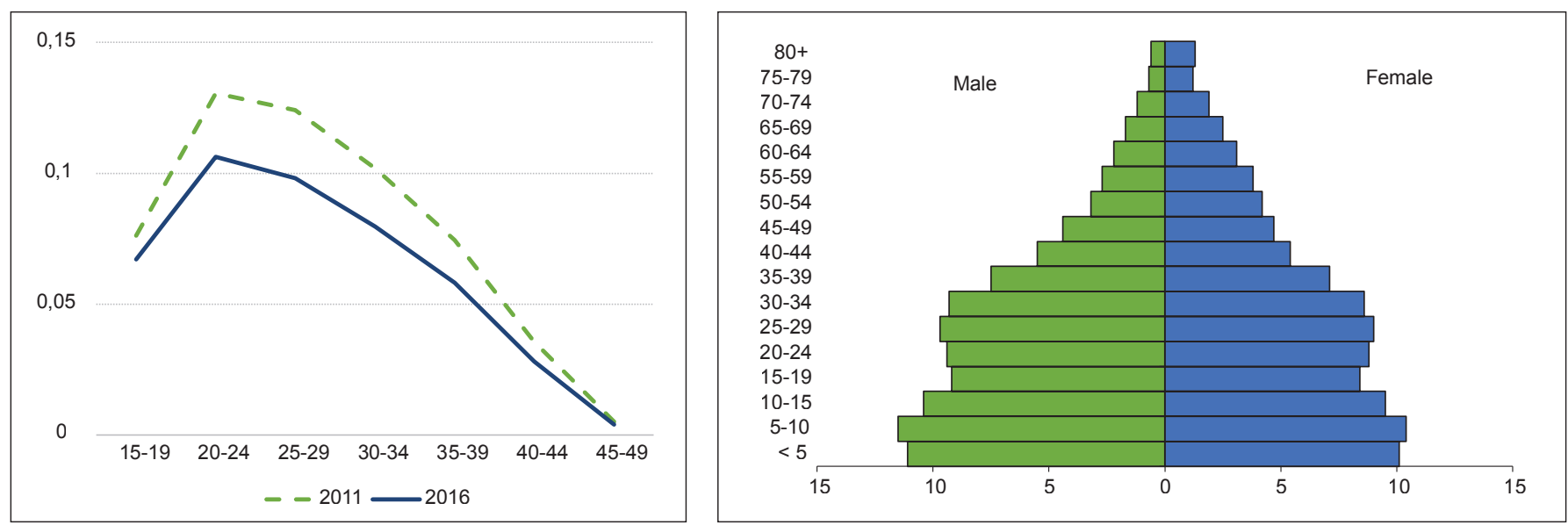

\subsection{Health}

The province of KwaZulu-Natal has high levels of mortality, mostly attributable to higher levels of HIVIAIDS in the province, which is the highest in the country at 30\% for women and men of reproductive ages (15-49) in 2016. The epidemic continue to affect women at $37 \%$ and $19 \%$ for women and men, respectively. This is coupled with an infant mortality rate of 40 per 1,000 live births. Although this is not the among the highest rates in the province aim to realise the demographic dividend. The survey asked women if they have problems in accessing health care. The provincial distribution of women 15 years and older with health-care access problems were - getting permission to go to the doctor (24\%); lack of money for advise or treatment (28\%); distance to health care facility (30\%); and not wanting to go alone (25\%). $40 \%$ of women reported to have a problem in at least one of the areas listed, further stressing the importance of exploring health care provision in the province.

Figure 7: Age-sex structure of KwaZulu-Natal population by district

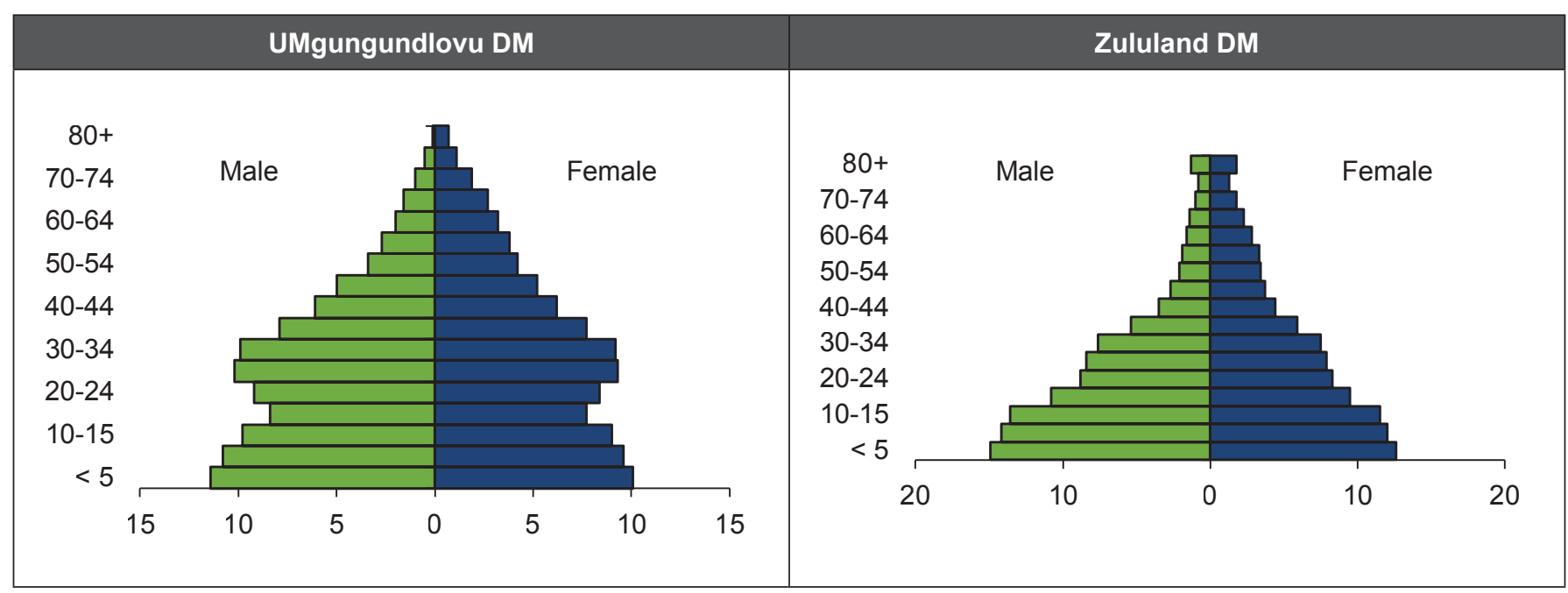




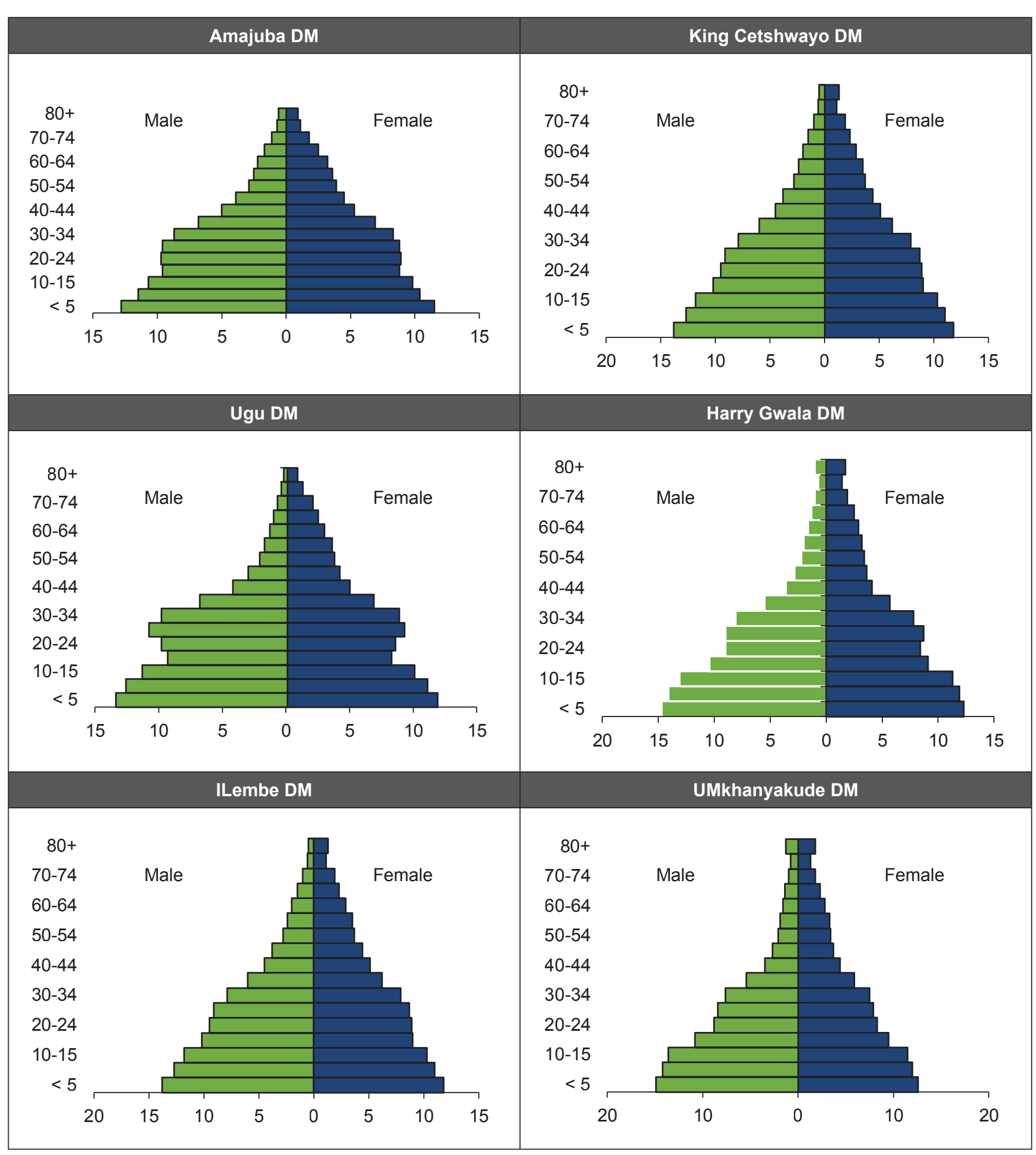




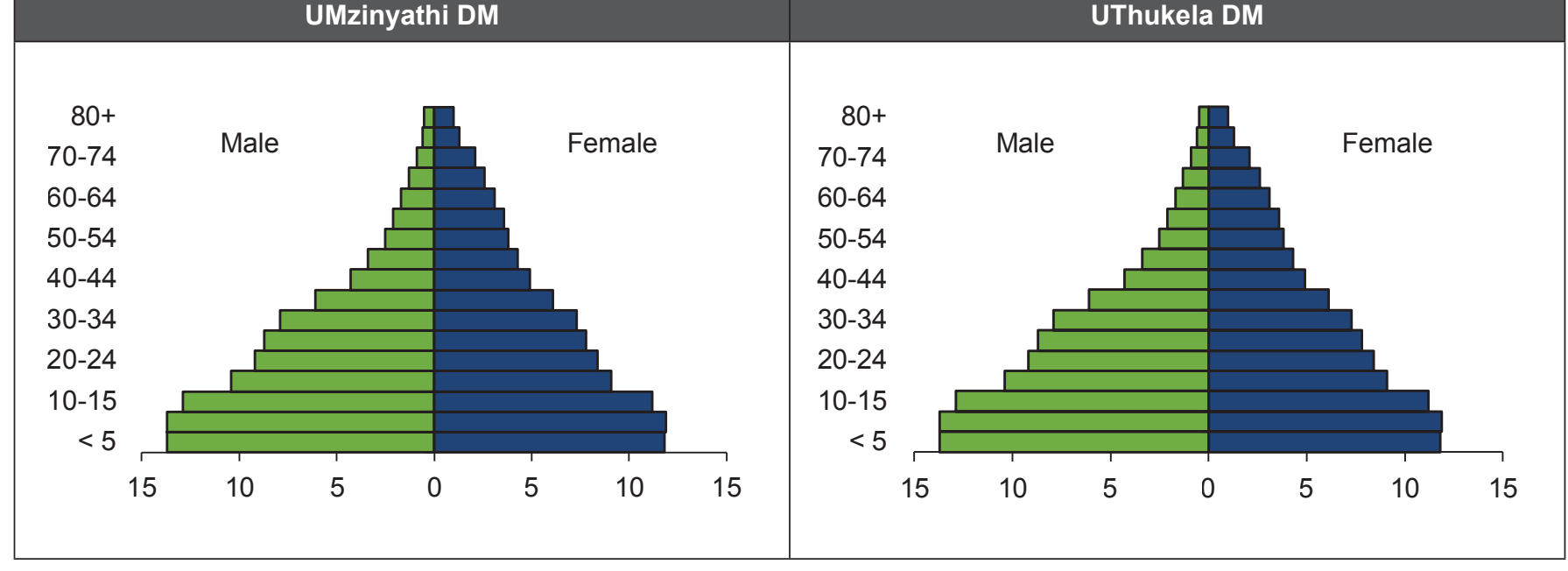

\section{IMPLICATION OF THE DEMOGRAPHIC PROSPECTS TO THE DD}

The province is experiencing a larger youth population, and a large number of children under the age of 9 year. There is evidence that the youth bulge will be more pronounced around 2029, when the 5-9 year olds in 2019 reach the 15-19. To maximize the DD, KwaZulu-Natal should concurrently prioritize investments in youth development - as there is evidence of a consistent large youth population in the next two decades. There also has to be a massive investment in child education, including early childhood - to ensure preparedness of this group by the time they reach age of economic activity (Bloom et al., 2002).

Based on the demographic profile, the specific policy and planning actions required by the province to reap the DD in a decade are:

\subsection{Health and wellbeing}

- $\quad$ Address youth health. This includes, family planning; HIVIAIDS; and related health concerns.

- $\quad$ Provide a conducive environment for child health, including immunization programmes and primary health care

- Invest in elderly health care

\subsection{Education and skills development}

- Increase investments in education, including universal secondary and higher education

- Increase investments in early childhood development

- Address quality issues, school dropout rates, and sex differences in enrollment

\subsection{Employment and entrepreneurship, and youth empowerment}

- Encourage investment in fast-growing, labour-intensive sectors such as construction, modern agriculture, and agroprocessing

- Invest in the development of economic infrastructure including energy, transportation, and communication

- Introduce entrepreneurial skills development

\section{INDICATORS FOR ASSESSING THE INTEGRATION OF THE DD INTO IDPS}

A situation analysis in an IDP is a systematic collection and evaluation of past and present economic and social data, aimed at firstly, identification of the general state of internal and external forces that may influence the municipality's choice of development planning strategies, and secondly, assessment of the municipality's current and future competitive position, operating condition and financial condition. The situation analysis in the IDP main focuses on data relating to demographic composition, health and well-being, education and skills development, and employment, entrepreneurship and youth empowerment. The summary of gaps identified in the situation analysis of each District Municipality is shown in Figure 7. As shown, there is homogeneity in gaps identified irrespective of the demographic prospects of the Municipality. The gaps are summaries below focusing on each pillar of the demographic dividend. 
Table 1: Indicators guiding the IDP

\section{Demographic variables \\ Situation analysis \\ - Disaggregation of the population by age and sex \\ - Is the dependency ratio/working age ratio presented? \\ - Are population projections presented? \\ - - are they disaggregated by age and sex? \\ - Youth population analysed? \\ - Is DD mentioned in the IDP? \\ - outline how the DD is
mentioned}

Health and wellbeing
Education and skills development
Employment and

entrepreneurship, and youth empowerment
- Is fertility analysis part of the plan?

- teenage childbearing

- Analysis of disability

- Gap analysis

- Were gaps assessed for each indicator?

- List gaps indicated

\section{- Poverty levels}

- are these disaggregated by demographic characteristics?

- are these disaggregated by small geographic location?

- Mortality analysis

- by age and sex

- infant mortality

- causes of death

- Which health measures were used?

- Youth health

- extent of analysis

- were health gaps identified

- Health access in the district

- sexual and reproductive health

- Provision of basic services: water and sanitation

- Gap analysis

- Were gaps assessed for each indicator?

- List gaps indicated
- Inclusion of educational information

- The extent of inclusion of educational assessment:

- by age-groups

- by sex/gender

- by level of education

- extent of school dropouts

- by geography

- Inclusion of skills assessment

- extent of the analysis

- Gap analysis

- Were gaps assessed for each indicator?

- List gaps indicated
- Inclusion of unemployment analysis

- Extent of employment analysis

- by sex/gender

- by sector (formal/ informal)

- Assessment of entrepreneurship activities in the district

- Are youth involved in entrepreneurship activities?

- which activities are listed?

- Is youth empowerment mentioned in the IDP?

- how is it operationalized?

- Gap analysis

- Were gaps assessed for each indicator?

- List gaps indicated

Identified programs

- Do programs align with the age-structure?

- List programs according to the indicators identified in the situation analysis

- Which indicators/gaps identified don not have programs/plans?

\section{- Extent of engagement} with the department of Health

- Extent of engagement with the department of Social Development

- List programs according to the (alignment with) indicators identified in the situation analysis

- Which indicators/gaps identified in the situation analysis do not have programs/plans?
- Engagement with the department of education and other relevant sector dpts

- List programs according to the indicators identified in the situation analysis

- Which indicators/gaps identified don not have programs/plans?
- Extent of engagement with other sector departments

- Economic generation programs/activities?

- Programs that engage unemployed youth

- Youth training activities through workshops, etc

- List programs according to the indicators identified in the situation analysis

- Which indicators/gaps identified don not have programs/plans? 


\begin{tabular}{|c|c|c|c|}
\hline Demographic variables & Health and wellbeing & $\begin{array}{l}\text { Education and skills } \\
\text { development }\end{array}$ & $\begin{array}{l}\text { Employment and } \\
\text { entrepreneurship, and } \\
\text { youth empowerment }\end{array}$ \\
\hline \multicolumn{4}{|l|}{ Budget } \\
\hline $\begin{array}{l}\text { Does the budget align } \\
\text { with demographic } \\
\text { indicators/gaps and } \\
\text { programs? }\end{array}$ & $\begin{array}{l}\text { Assessment of budget } \\
\text { alignment with programs } \\
\text { and gaps identified }\end{array}$ & $\begin{array}{l}\text { Assessment of budget } \\
\text { alignment with programs } \\
\text { and gaps identified }\end{array}$ & $\begin{array}{l}\text { Assessment of budget } \\
\text { alignment with programs } \\
\text { and gaps identified }\end{array}$ \\
\hline
\end{tabular}

\subsection{Demographic Variables}

The general observation was that KwaZulu-Natal District Munucipalities (DM) disaggregated the population of the municipality by age and sex mostly based on the Community Survey of 2016. The population projections were largely absent, except for the Ethekwini Municipality which presented disaggregated estimates by age and sex for the period between 2019 and 2023. No reference to demographic dividend was made by any DM, despite that the population profiles of eThekwini and UMgungundlovu Districts show an existence of a youth bulge (summarized in Table 2 below).

Other demographic indicators such as the dependency ratio, sex ratios were commonly presented by the Districts. However, there were no links from this data to its implications on the provision of infrastructure services and amenities, and proposed programmes and projects that are adopted and funded in the IDPs. Perhaps the most omission was the lack of detail in the analysis of youth population in eThekwini and UMgungundlovu District. The lack of such information makes it difficult for development planners to know the number of the youth population and how to target projects that are meant to improve their knowledge, skills and opportunities for employment or to create employment.

Also noticeable was the lack of analysis of persons with disability and other vulnerable populations in the IDPs. Some presented general statistics on disability gathered from the Stats SA Community Survey 2016 , but no analysis was provided. The lack of such analysis is reflected in the lack of projects in the 2019/20 IDP meant to improve the life of persons with disability.

Data on the fertility rate and teenage pregnancy rates was scant if at all presented. There is no explicit fertility analysis in the IDPs, which was expected for 9 of the 11 Districts that have young age structures. Without data on fertility rates and teenage pregnancy levels planners are unable to adequately plan and provide resources to deal with this known factor that affect women's ability to reach their human development potential (higher school drop-outs). Early childbearing is associated with significant health risks (maternal morbidity and mortality) and socio-economic costs. As a result of this exclusion, Districts lacked strategies of resolving the plight of teen mothers who have a higher likelihood of poorer educational outcomes, which has negative implications for their economic prospects.

\subsection{Health and Well-being}

The 2019/20 IDPs made mention of high poverty levels within the Districts, but largely did not provide a clear disaggregation of the poverty levels according to geographic localities; population groups; age and sex. The province has high prevalence of poverty, which likely perpetuate negative outcomes. Certainly, poverty has a direct impact to the prospects of reaping the demographic dividend through its links with higher negative health and human capital outcomes.
The 2019/20 IDPs provide a short mortality analysis based on data gathered from Statistics South Africa and research conducted by Health Systems Trust. Most provided an analysis of 10 leading causes of death by age group. However, there is no disaggregation of mortality according to sex. HIV/Aids prevalence was also largely included by the Districts through it did not include disaggregation by age-group, sex and geographic location.

Although several issues affecting the health of the youth including the high prevalence of STIs, HIVIAIDS and Tuberculosis were identified in the 2019/20 IDPs these were mostly vague and had no detailed analysis of the health of the youth. The provincial population is prone to premature deaths are the result of behaviours begun in adolescence, many of which relate to social ills such as excessive drugs, alcohol and tobacco use. Excessive substance abuse are linked to increased physical and sexual violence and riskier sexual behaviour, which increases risks of HIV and STIs. However, the 2019/20 IDPs appear to offer no strategies of intervening early that could enhance young people's wellbeing and ensuring better health in the future.

Although there were challenges identified by Districts in the 2019/20 IDPs affecting the health of the youth, i.e. high prevalence of STIs, HIVIAIDS and Tuberculosis, there is no information provided on or analysis of access to sexual and reproductive health and rights (SRHR) services disaggregated according to age group, sex and geographic location. This is considered a major gap identified in all District IDPs. 


\subsection{Education and Skills Development}

The 2019/20 IDP presented by Districts included some educational information, but this information lacked specific details by geography of student-to-teacher ratio or student-to-teaching equipment and materials. Moreover the education information provided does not indicate the quality of education provided at primary and secondary school level and the pass rate especially for problematic subjects such as science, mathematics and accounting.

The educational assessment conducted often includes general information on the levels of education across the municipality and the levels of illiteracy, but the number of people with matriculation and higher educational qualifications is not provided. The education information provided in the IDP lacks specific details on number, age groups and sex of school-going children, the level of enrolment and rate of school drop-out by geographic location in each of these municipality.

The skills assessment either note presented of was a based on statistics relating to the percentage of adults with post matric qualifications.

\subsection{Employment and Entrepreneurship and Youth Empowerment}

The 2019/20 IDP IDPs report show unemployment rates based on the Quarterly Labour Force Survey (QLFS), but there was no analysis of this data according to sex and geographic location in each DM. There was also no analysis of unemployment according to sector of the economy - whether in the formal or informal sector in each DM. This is a challenge for the municipality to know which localities under their jurisdiction is unemployment highest or which sectors of the economy need stimulus packages to induce economic growth and create employment for specific age groups, sex and population groups. This despite that all $2019 / 20$ IDP make broad mention of the goal to promote entrepreneurship activities.

Table 2: Assessing the integration of the demographic dividend into IDPs

\begin{tabular}{|c|c|c|c|c|}
\hline EThekwini & Amajuba & Harry Gwala & Ilembe & King Cetswayo \\
\hline \multicolumn{5}{|c|}{ Demographic prospects } \\
\hline Late transition & Early transition & Pre-transition & Early-transition & Early transition \\
\hline Mid-dividend & Pre-dividend & Pre-dividend & Pre-dividend & Pre-dividend \\
\hline Youth bulge & Young profile & Young profile & Young profile & Young profile \\
\hline $\begin{array}{l}\text { Dependency ratio = } \\
44 \%\end{array}$ & $\begin{array}{l}\text { Dependency ratio = } \\
60 \%\end{array}$ & $\begin{array}{l}\text { Dependency ratio = } \\
80 \%\end{array}$ & $\begin{array}{l}\text { Dependency ratio = } \\
64 \%\end{array}$ & $\begin{array}{l}\text { Dependency ratio = } \\
68 \%\end{array}$ \\
\hline
\end{tabular}

Key gaps: Integration of DD into the IDP

\begin{tabular}{|c|c|c|c|c|}
\hline $\begin{array}{l}\text { No reference to } \\
\text { Demographic Dividend } \\
\text { or how it applies to the } \\
\text { population profile } \\
\text { There was limited } \\
\text { analysis of the Youth } \\
\text { population. } \\
\text { There was no } \\
\text { analysis of persons } \\
\text { with disability in the } \\
\text { population. } \\
\text { Poverty levels are } \\
\text { not disaggregated } \\
\text { by demographic } \\
\text { characteristics. }\end{array}$ & $\begin{array}{l}\text { There is no mention } \\
\text { of fertility rates and } \\
\text { teenage pregnancy } \\
\text { statistics in the IDP } \\
\text { Poor participation of } \\
\text { stakeholders during } \\
\text { the IDP development } \\
\text { process. Data issues } \\
\text { - identified during the } \\
\text { workshop } \\
\text { Although poverty } \\
\text { levels are well } \\
\text { analysed, there is no } \\
\text { disaggregation by } \\
\text { age/sex profile of the } \\
\text { district. }\end{array}$ & $\begin{array}{l}\text { The } 2019 / 20 \text { IDP does } \\
\text { not provide population } \\
\text { projections that are } \\
\text { disaggregated by age } \\
\text { and sex. } \\
\text { The fertility rate } \\
\text { together with teenage } \\
\text { pregnancy rates are } \\
\text { not stated or analysed } \\
\text { in the } 2019 / 20 \text { IDP } \\
\text { There is no analysis of } \\
\text { vulnerable population } \\
\text { Poverty levels are } \\
\text { not disaggregated } \\
\text { by demographic } \\
\text { characteristics. }\end{array}$ & $\begin{array}{l}\text { The dependency ratio } \\
\text { and working age ratio } \\
\text { are not stated in the } \\
\text { IDP } \\
\text { The population <15 } \\
\text { years was analysed. } \\
\text { This is the largest } \\
\text { population in the } \\
\text { district. } \\
\text { The } 2019 / 20 \text { IDP does } \\
\text { not provide population } \\
\text { projections that are } \\
\text { disaggregated by age } \\
\text { and sex. }\end{array}$ & $\begin{array}{l}\text { The dependency ratio } \\
\text { and working age ratio } \\
\text { are not stated in the } \\
\text { IDP } \\
\text { The population }<15 \\
\text { years was analysed. } \\
\text { This is the largest } \\
\text { population in the } \\
\text { district. } \\
\text { No population } \\
\text { projections that are } \\
\text { disaggregated by age } \\
\text { and sex } \\
\text { No mention of } \\
\text { access to sexual and } \\
\text { reproductive health } \\
\text { services }\end{array}$ \\
\hline
\end{tabular}




\begin{tabular}{|c|c|c|c|c|}
\hline EThekwini & Amajuba & Harry Gwala & Ilembe & King Cetswayo \\
\hline $\begin{array}{l}\text { An analysis of } \\
\text { Youth health } \\
\text { was exhaustively } \\
\text { conducted and hence } \\
\text { the IDP is unable to } \\
\text { clearly identify its } \\
\text { health gaps. } \\
\text { There is no } \\
\text { information provided } \\
\text { on access to health } \\
\text { facilities access in the } \\
\text { Municipality. } \\
\text { The IDP does not } \\
\text { make any mention } \\
\text { of sexual and } \\
\text { reproductive health. } \\
\text { Education levels not } \\
\text { disaggregated }\end{array}$ & $\begin{array}{l}\text { There is no } \\
\text { disaggregation of } \\
\text { mortality according } \\
\text { to the prevailing sex } \\
\text { profile of the District. } \\
\text { The IDP does not } \\
\text { provide analysis of } \\
\text { access to sexual and } \\
\text { reproductive health } \\
\text { services } \\
\text { Education and skills } \\
\text { assessment } \\
\text { Education not } \\
\text { disaggregated by age, } \\
\text { sex, geography and } \\
\text { the extent of school } \\
\text { drop-outs }\end{array}$ & $\begin{array}{l}\text { There is no } \\
\text { disaggregation of } \\
\text { mortality according } \\
\text { to the prevailing sex } \\
\text { profile of the District. } \\
\text { There is no } \\
\text { disaggregation of the } \\
10 \text { leading causes of } \\
\text { death, by age and sex } \\
\text { Education not } \\
\text { disaggregated by age, } \\
\text { sex, geography and } \\
\text { the extent of school } \\
\text { drop-outs }\end{array}$ & $\begin{array}{l}\text { Poverty levels are } \\
\text { not disaggregated } \\
\text { by demographic } \\
\text { characteristics or } \\
\text { geographic location. } \\
\text { There is no } \\
\text { disaggregation of } \\
\text { mortality according } \\
\text { to the prevailing } \\
\text { demographic profile of } \\
\text { the District. } \\
\text { The IDP does not } \\
\text { make any mention of } \\
\text { access to sexual and } \\
\text { reproductive health } \\
\text { services with the } \\
\text { District. } \\
\text { Education not } \\
\text { disaggregated by age, } \\
\text { sex, geography and } \\
\text { the extent of school } \\
\text { drop-outs }\end{array}$ & $\begin{array}{l}\text { The IDP does not } \\
\text { include a breakdown } \\
\text { of education levels } \\
\text { according to age, sex, } \\
\text { geography and the } \\
\text { extent of school drop- } \\
\text { outs. } \\
\text { The skills assessment } \\
\text { was not disaggregated } \\
\text { further to consider } \\
\text { the municipality's } \\
\text { demographic profile. }\end{array}$ \\
\hline
\end{tabular}

\begin{tabular}{|c|c|c|c|c|c|}
\hline UMgungundlovu & Ugu & UThukela & UMzinyathi & Zululand & UMkhanyakude \\
\hline \multicolumn{6}{|c|}{ Demographic prospects } \\
\hline $\begin{array}{l}\text { Late transition } \\
\text { Mid-dividend } \\
\text { Youth bulge + } \\
\text { young population } \\
\text { Dependency ratio } \\
=53 \%\end{array}$ & $\begin{array}{l}\text { Early transition } \\
\text { Pre-dividend } \\
\text { Young profile } \\
\text { Dependency ratio } \\
=68 \%\end{array}$ & $\begin{array}{l}\text { Early transition } \\
\text { Pre-dividend } \\
\text { Young profile } \\
\text { Dependency ratio } \\
=72 \%\end{array}$ & $\begin{array}{l}\text { Early transition } \\
\text { Pre-dividend } \\
\text { Young profile } \\
\text { Dependency ratio } \\
=80 \%\end{array}$ & $\begin{array}{l}\text { Pre-transition } \\
\text { Pre-dividend } \\
\text { Young profile } \\
\text { Dependency ratio } \\
=80 \%\end{array}$ & $\begin{array}{l}\text { Pre-transition } \\
\text { Pre-dividend } \\
\text { Young profile } \\
\text { Dependency ratio } \\
=76 \%\end{array}$ \\
\hline \multicolumn{6}{|c|}{ Key gaps: Integration of DD into the IDP } \\
\hline $\begin{array}{l}\text { No reference to } \\
\text { Demographic } \\
\text { Dividend or how } \\
\text { it applies to the } \\
\text { population profile } \\
\text { No population } \\
\text { projections that } \\
\text { are disaggregated } \\
\text { by age and sex } \\
\text { The fertility } \\
\text { rate together } \\
\text { with teenage } \\
\text { pregnancy rates } \\
\text { are not analysed }\end{array}$ & $\begin{array}{l}\text { The } 2019 / 20 \\
\text { IDP does not } \\
\text { provide population } \\
\text { projections that } \\
\text { are disaggregated } \\
\text { by age and sex. } \\
\text { The fertility } \\
\text { rate together } \\
\text { with teenage } \\
\text { pregnancy rates } \\
\text { are not stated or } \\
\text { analysed in the } \\
2019 / 20 \text { IDP }\end{array}$ & $\begin{array}{l}\text { The } 2019 / 20 \\
\text { IDP does not } \\
\text { provide population } \\
\text { projections that } \\
\text { are disaggregated } \\
\text { by age and sex } \\
\text { Poverty levels are } \\
\text { not disaggregated } \\
\text { by demographic } \\
\text { characteristics. }\end{array}$ & $\begin{array}{l}\text { No reference to } \\
\text { Demographic } \\
\text { Dividend or how } \\
\text { it applies to the } \\
\text { population profile } \\
\text { of the District } \\
\text { The population } \\
<15 \text { years was } \\
\text { analysed. This } \\
\text { is the largest } \\
\text { population in the } \\
\text { district. }\end{array}$ & $\begin{array}{l}\text { The } 2019 / 20 \\
\text { IDP does not } \\
\text { provide population } \\
\text { projections that } \\
\text { are disaggregated } \\
\text { by age and sex. } \\
\text { The fertility } \\
\text { rate together } \\
\text { with teenage } \\
\text { pregnancy rates } \\
\text { are not stated or } \\
\text { analysed in the } \\
2019 / 20 \text { IDP }\end{array}$ & $\begin{array}{l}\text { Basic } \\
\text { demographic } \\
\text { indicators not } \\
\text { provided } \\
\text { Poverty levels are } \\
\text { not disaggregated } \\
\text { by demographic } \\
\text { characteristics. } \\
\text { There is no } \\
\text { disaggregation } \\
\text { of mortality } \\
\text { according to the } \\
\text { prevailing sex } \\
\text { profile of the } \\
\text { District. }\end{array}$ \\
\hline
\end{tabular}




\begin{tabular}{|c|c|c|c|c|c|}
\hline UMgungundlovu & Ugu & UThukela & UMzinyathi & Zululand & UMkhanyakude \\
\hline $\begin{array}{l}\text { No analysis of } \\
\text { people living with } \\
\text { disability } \\
\text { District } \\
\text { health is not } \\
\text { comprehensive } \\
\text { Education not } \\
\text { disaggregated } \\
\text { by age, sex, } \\
\text { geography and } \\
\text { the extent of } \\
\text { school drop-outs }\end{array}$ & $\begin{array}{l}\text { Poverty levels are } \\
\text { not disaggregated } \\
\text { by demographic } \\
\text { characteristics. } \\
\text { There is no } \\
\text { disaggregation } \\
\text { of mortality } \\
\text { according to the } \\
\text { prevailing sex } \\
\text { profile of the } \\
\text { District. } \\
\text { Education not } \\
\text { disaggregated } \\
\text { by age, sex, } \\
\text { geography and } \\
\text { the extent of } \\
\text { school drop-outs }\end{array}$ & $\begin{array}{l}\text { There is no } \\
\text { disaggregation } \\
\text { of mortality } \\
\text { according to the } \\
\text { prevailing sex } \\
\text { profile of the } \\
\text { District. } \\
\text { There is no } \\
\text { disaggregation } \\
\text { of the } 10 \text { leading } \\
\text { causes of death, } \\
\text { by age and sex } \\
\text { Education not } \\
\text { disaggregated } \\
\text { by age, sex, } \\
\text { geography and } \\
\text { the extent of } \\
\text { school drop-outs }\end{array}$ & $\begin{array}{l}\text { The } 2019 / 20 \\
\text { IDP does not } \\
\text { provide population } \\
\text { projections that } \\
\text { are disaggregated } \\
\text { by age and sex } \\
\text { Poverty levels are } \\
\text { not disaggregated } \\
\text { Mortality not } \\
\text { disaggregated } \\
\text { by prevailing } \\
\text { sex profile of the } \\
\text { District. } \\
\text { Education not } \\
\text { disaggregated } \\
\text { by age, sex, } \\
\text { geography and } \\
\text { the extent of } \\
\text { school drop-outs }\end{array}$ & $\begin{array}{l}\text { Poverty levels are } \\
\text { not disaggregated } \\
\text { by demographic } \\
\text { characteristics. } \\
\text { There is no } \\
\text { disaggregation of } \\
\text { infant mortality, } \\
\text { mortality } \\
\text { according to the } \\
\text { prevailing sex } \\
\text { profile of the } \\
\text { District. } \\
\text { There is no } \\
\text { disaggregation } \\
\text { of the } 10 \text { leading } \\
\text { causes of death, } \\
\text { by age and sex }\end{array}$ & $\begin{array}{l}\text { The } 2019 / 20 \\
\text { IDP does not } \\
\text { indicate the levels } \\
\text { of accessibility } \\
\text { to health care } \\
\text { facilities } \\
\text { There is no } \\
\text { disaggregation } \\
\text { of the } 10 \text { leading } \\
\text { causes of death, } \\
\text { by age and sex } \\
\text { No education } \\
\text { levels according } \\
\text { to age, sex, } \\
\text { geography and } \\
\text { the extent of } \\
\text { school drop-outs }\end{array}$ \\
\hline
\end{tabular}

\section{CONCLUSIONS AND RECOMMENDATIONS}

The majority of Districts in KwaZulu-Natal ( 9 of 11) are at pre and early dividend stages. These districts have young populations characterized by large numbers of children under the age of 15 . These Districts are at early demographic transition stages suggesting that a closer focus on children is crucial to prepare this population for future dividend. Two Districts, a Metro and the capital city of the province, are at mid-transition (EThekwini and UMgungundovu). The resounding silence of the demographic dividend in their IDPs is likely to hamper the likelihood of the Districts from reaping the DD. Lessons learned from this study suggest that to make a more meaningful impact, IDPs from local Municipalities (LM) should be included. The majority of planning and service delivery takes place at a LM level, therefore ensuring that their IDPs respond to issues related to the demographic dividend is important. This could be done in the same model followed for Districts, but ensuring that IDP indicators are adjusted for each LM. This is because it is clear from the demographic prospects of DMs that each has a unique demographic transition, therefore at varying stages of the dividend. As such, more tailor made DD instruments are required. It is also critical to follow up on how the DD is incorporated in future (time-periods) IDPs at a District and Local Municipal level. This would assist in ensuring a sustainable response to the demographic demands of the District as demographic prospects change. 


\section{REFERENCES}

BLOOM, D. E., CANNING, D. \& SEVILLA, J. 2003. The demographic dividend: A new perspective on the economic consequences of population change. In: COMMUNICATION, A. R. P. O. P.-R. R. (ed.).

BOOTH, H. 1984. Transforming Gompertz's Function for Fertility Analysis: The Development of a Standard for the Relational Gompertz Function. Population Studies, 38, 495506.

COHEN, S. A. 2004. Delayed marriage and abstinence-until-marriage: On a collision course. The Guttmacher Report on Public Policy 7, 3.

GRIBBLE, J. \& BREMMER, J. 2012. The challenge of attaining the demographic divindend. In: BUREAU, P. R.-. (ed.) Policy brief.

INTERNATIONAL-STATISTICALREVIEW 1973. The World Fertility Survey: An International Programme of Fertility Research. International Statistical Review, 41, 11.

KAUFMAN, C. E. 1998. The Politics of Contraception in South Africa. Women's Studies International Forum, 13, 10.

LESTHAEGHE, R. 1985. Value Orientations, Economic Growth and Demographic Trends - Towards a

Confrontation. IPD Working Papers. Brussel

MAKIWANE, M. \& CHIMERE-DAN, G. 2009. The State of Youth in South Africa. In: COUNCIL, H. S. R. (ed.). Pretoria.

MASON, A. 2003. Capitalizing on the demographic dividend. In: FUND, U. N. P. (ed.) Population and poverty: Achieving equity, equality and sustainability. New York: UNFPA.

MASON, A. 2007. Demographic transition and demographic dividends in developed and developing countries. In: UNITED-NATIONS (ed.) United Nations expert group meeting on social and economic implications of changing population age structures. New York: Department of economic and social affairs.
MOULTRIE, T., DORRINGTON, R. HILL, A., HILL, K., TIMAEUS, I. \& ZABA, B. 2013. Tools for Demographic Estimation. In: POPULATION, I. U. F. T. S. S. O. (ed.). Paris.

MOULTRIE, T. A. 2013. General assessment of age and sex data. In: MOULTRIE, T., DORRINGTON, R., HILL, A., HILL, K., TIMÆEUS, I. \& ZABA, B. (eds.) Tools for Demographic Estimation. Paris: International Union for the Scientific Study of Population.

OOSTHUIZEN, M. J. 2015. Bonus or mirage? South Africa's demographic dividend. The Journal of the Economics of Ageing, 5, 8.

PANDAY, D., MAKIWANE, M., RANCHOD, C. \& LETSOALO, T. 2009. Teenage pregnancy in South Africa: with a specific focus on school going learners. In: COUNCIL, H. S. R. (ed.). Pretoria-South Africa.

POPULATION-REFERENCE-BUREAU 2017. The Demographic Dividend in Africa Relies on Investments in the Reproductive Health and Rights of Adolescents and Youth Policy Brief. New York.

POPULATION-REFERENCE-BUREAU 2017a. World Population Data Sheet with special focus on youth. In: UNITED-NATIONS (ed.). New York.

PRESON-WHYTE, E., ZONDI, E., MAVUNDLA, G. \& GUMEDE, H. 1990. Teenage pregnancy, whose problem? Realities and prospects for action in KwaZulu Natal. South African Medical Journal, 77, 9.

STATSSA 1998. Census in Brief. In: AFRICA, S. S. (ed.) The people of South Africa population census 1996. Pretoria, South Africa.

STATSSA 2003. Census in Brief. In: AFRICA, S. S. (ed.) Census 2001 in Brief.

STATSSA 2012. Census in Brief. In: AFRICA, S. S. (ed.) Census 2011 in Brief. Pretoria.
STATSSA 2017a. Mortality and causes of death in South Africa, 2015: Findings from death notification. In: STATSSA (ed.). Pretoria.

STATSSA 2017b. Mid-year population estimates. In: STATSSA (ed.). Pretoria.

UDJO, E. O. 2005. An evaluation of age-sex distributions of South Africa's population within the context of HIV/ AIDS. Development Southern Africa, 22, 319-345.

UDJO, E. O. 2014a. Estimating demographic parameters from the 2011 South Africa Population Census. African Population Studies, 28.

UDJO, E. O. 2014b. Estimating demographic parameters from the 2011 South Africa population census. African Population Studies, 28, 564-578.

UNITED-NATIONS 2007. United Nations expert group meeting os social and economic implications of changing population age structures, New York.

VIRGILIO, P.-B. 2007. Demographic transition, demographic bonus and ageing in Mexico. In: UNITEDNATIONS (ed.) United Nations expert group meeting on social and economic implications of changing age structures. New York: Department of Economic and Social Affairs.

WILLAN, S. 2013. A Review of Teenage Pregnancy in South Africa - Experiences of Schooling, and Knowledge and Access to Sexual \& Reproductive Health Services. In: TRUST, H. S. (ed.).

ZABA, B. 1981. Use of the relational Gompertz model in analysis fertility data collected in retrospective surveys. In: MEDICINE, L. S. O. H. A. T. (ed.). 